\title{
The Relationship of Prior Ability and Family Characteristics to School Attendance and School Achievement in Rural Guatemala
}

\author{
Mare Irwin, Patricia L. Engle, Charles Yarbrough, \\ Robert E. Klein, and John Townsend \\ Institute of Nutrition of Central America and Panama (INCAP), \\ Guatemala City, Guatemala
}

\begin{abstract}
Data from a longitudinal study in progress were used to investigate the relationships between intellectual ability prior to schooling opportunities and characteristics of family and home environment, and elementary school attendance and performance in 3 rural Guatemalan communities. Pre-school- ing mental test performances, family SES level, and indices of parental values concerning edu- cation were all associated with attending or not attending school. Length of school attendance was predicted by preschooling mental test scores for girls and by family SES level and parental values for boys. Age at first enrollment was predicted by both pre-schooling mental test scores and family SES level for both sexes. School grades were predicted by pre-schooling mental test scores and intellectual stimulation provided in the home but not by family SES level. It is argued that schooled and nonschooled peers in most semiliterate communities are unlikely to be originally comparable, and that conclusions based on previous studies of the effects of formal schooling on intellectual development must be reconsidered.
\end{abstract}

In Western industrialized countries, going to school has the same inevitability for children that death and taxes have for their parents. In developing countries, school attendance is far from inevitable. Although some children do enroll in school, sizable numbers of their peers receive no formal instruction. Knowing who goes to school under such circumstances is important for those concerned with national development. It is also important to psychologists, who have recognized that such settings represent natural designs through which the effects of formal instruction on cognitive development may be studied.

The information from psychological studies of schooling in such settings is contradictory. Some investigators report basic cognitive deficits among unschooled children (Greenfield \& Bruner 1966 [working in Senegal]; Goodnow \& Bethon 1966 [in Hong Kong]; Evans \& Segall 1969, and Okonji 1971 [in Uganda]; Owoc 1973 [in Nigeria]; Page 1973 [in South
Africa]). Others, employing similar tasks, do not (Fahrmeier 1975, and Price-Williams 1961, 1962 [in Nigeria]; Mermelstein \& Shulman 1967 [in a southern U.S. community which closed schools rather than integrate them]). The data of Cole and his co-workers from Liberia (e.g., Cole, Gay, Glick, \& Sharp 1971; Cole \& Scribner 1974; Scribner \& Cole 1973) and more recently from Yucatán (Sharp, Cole, \& Lave, Note 1) suggest that schooled and unschooled children do not differ in basic cognitive abilities, but do differ in the way these abilities get organized into learning and problem-solving strategies.

The issue of whether or not formal schooling has generalized effects on cognitive functioning, as Greenfield and Bruner (1966) and Scribner and Cole (1973) among others have argued, is unlikely ever to be resolved on the basis of studies of the kind performed to date. All previous schooling studies, except Fahrmeier's (1975), have been post hoc, measur-

This research was partially supported by contract no. NO1-HD-5-0640 from the National Institute of Child Health and Human Development, and by National Science Foundation grant no. BNS76-82639 to Marc Irwin and Robert E. Klein. We wish to express our gratitude to Dorothy Eichorn and to Michael Cole for their comments on an earlier draft of this paper. Author Irwin's address: Division of Human Development, Institute of Nutrition of Central America and Panama (INCAP), P.O. Box 1188. Guatemala Citv. Guatemala. Central Amerina 
ing cognitive performances after one group of children, but not another, had formal instruction. Comparability of schooled and unschooled subjects before entering school was assumed. Fahrmeier's study used a cross-sectional design in which groups having from none to 6 years of schooling were compared to unschooled age-matched peers. He found significant differences favoring school-enrolled 6and 7-year-olds over nonenrolled peers on a cylinder matrix task (see Bruner \& Kenney 1966) 1 week after these children had begun their schooling, as well as significant differences favoring these children on a science information test 3 months after school had begun.

It is in fact probable that children who attend school in developing countries usually differ at school entrance from peers who do not attend. Even where no school fees are assessed, families must make some financial sacrifices to send a child to school. School supplies (and sometimes required school uniforms) cost money. Often an even larger cost to the family is the loss of a child's labor. In many parts of the developing world children begin making a small contribution to family survival at very young ages, and by the time they have reached adolescence their economic contribution is frequently equal to that of an adult. Under the straitened economic circumstances of life in many Third World communities, the family economic level, parental values regarding the importance of formal education, and perceptions of a child's "schoolability" may each influence the decision of whether and when to send a child to school.

The ideal design for studying the effects of formal schooling on cognitive development is a longitudinal study that not only measures intellectual ability and factors that may affect cognitive development prior to school attendance but also measures cognitive performances subsequent to varying amounts of schooling. This paper reports results of the first part of such a study currently in progress: pre-schooling comparisons of a sample of subsequently schooled or unschooled rural Guatemalan children. In addition, pre-schooling correlates of age at school entry and of length of school attendance are examined.

Also examined are associations between the school success or achievement of children who attend school and their family characteristics and pre-schooling cognitive test performances. Mental test performance has been consistently found to correlate with school achievement in the United States (e.g., Anastasi 1968), and school achievement has in fact served as a validity criterion for intelligence tests since their inception (Tuddenham 1963). However, little is presently known about the relationship of mental test performances to school achievement in developing countries, although Vernon (1969) has reported significant correlations between mental test performance and school achievement among Jamaican children, as has Irvine (1966) among Rhodesian children.

Parental characteristics and behavior also have been reported to predict or correlate with school achievement for U.S. samples. Parental SES level, for example, has frequently been found to correlate with school achievement (California School Administrators Association 1962; Coleman 1966; Feldman \& Weiner 1964; Havighurst 1964; Tulkin 1968; Weiner \& Feldman 1963). Parental involvement with their children has also been reported to correlate with children's school achievement (Tulkin 1968; Van Doorninck, Caldwell, Wright, \& Frankenburg, Note 2), as have provision of appropriate toys and mother involvement with the outside world (Van Doorninck et al., Note 2).

Whether such family characteristics and preschool mental test performances will relate to subsequent school achievement among the rural Guatemalan children in the present study is difficult to predict on an a priori basis. Like many rural schools in developing countries, the schools attended by study children emphasize rote learning to a much greater extent than do most U.S. schools. Finding associations of family characteristics and pre-schooling mental test performances with school achievement comparable to those seen with U.S. samples would lend support to the arguments of Bruner, Olver, Greenfield, et al. (1966), and Scribner and Cole (1973), among others, that formal schooling constitutes a human experience that is not only significant but always essentially similar.

\section{Method}

Subjects.-Data for the present study were collected in three villages participating in the Institute of Nutrition of Central America and Panama's (INCAP) longitudinal study of the effects of nutrition and other variables on 
mental development. 1 These villages, which range in size from 800 to 1,200 inhabitants, are located in the Spanish-speaking eastern region of Guatemala. Nearly all families engage in subsistence agriculture, and poverty is pervasive. A brief ethnography of these villages has been provided in Nerlove, Roberts, Klein, Yarbrough, and Habicht (1974). A com plete ethnography can be found in MejíaPivaral (1972).

The sample described in this paper consists of virtually every child presently between 8 and 13 years of age residing in the three study communities. Thus, six age cohorts, each of which has been studied longitudinally since 1969 , are represented. Each child in the sample was tested on the INCAP Preschool Battery within a month of his or her seventh birthday. Seven years old is the Guatemalan legal public school entry age, so all children in the sample were tested previous to entering school. The six cohorts comprising the sample have had, to date, differing opportunities to attend school. The 77 8-year-olds (as of January 1976) in the sample have had one opportunity to attend a year of school, the 74 9-year-olds had two opportunities, the 79 10-year-olds three opportunities, the 55 11-year-olds four opportunities, the 67 12-year-olds five opportunities, and the 35 13-year-olds six oppor- tunities. Frequency breakdowns, for the entire sample, of age at first school enrollment and years of school attended, up to the time of data compilation, are given in tables 1 and 2 . It must be emphasized that these figures, as well as the data reported in the present paper, describe schooling experiences to date. Many of the children in the sample, particularly in the younger cohorts, have not yet finished their schooling. Ideally, of course, we would prefer to have and present data for children who have all completed their schooling. This will not be possible for this sample of children for several years. The possibility of biases due to differential opportunities to attend school exist in our data. The way we dealt with possible biases is described in the Results section.

Each village has only a government elementary school with grades 1-6, and attendance was within each child's village.

Psychological testing.-Pre-schooling tests are administered in Spanish by female Guatemalan testers. Testing takes place in adobe testing houses equivalent to village houses but equipped with one-way viewing mirrors. Testers are extensively trained, and their work is supervised in the field by a Central American psychologist. They are also checked twice yearly for intertester reliability.

TABLE 1

Ages of Children in Study Sample at First Enrollment in Schoola

\begin{tabular}{|c|c|c|c|c|c|c|c|c|}
\hline & \multicolumn{6}{|c|}{ AgEs (in Years) } & \multirow{2}{*}{$\begin{array}{l}\text { NeVER } \\
\text { ENROLLED }\end{array}$} & \multirow[b]{2}{*}{ TotaL } \\
\hline & 7 & 8 & 9 & 10 & 11 & 12 & & \\
\hline $\begin{array}{l}\text { Boys.......... } \\
\text { Girls........ }\end{array}$ & $\begin{array}{l}52 \\
45\end{array}$ & $\begin{array}{l}65 \\
66\end{array}$ & $\begin{array}{l}24 \\
20\end{array}$ & $\begin{array}{l}5 \\
8\end{array}$ & $\begin{array}{l}6 \\
3\end{array}$ & $\begin{array}{l}0 \\
1\end{array}$ & $\begin{array}{l}45 \\
47\end{array}$ & $\begin{array}{l}197 \\
190\end{array}$ \\
\hline
\end{tabular}

a Enrollment figures include children who enrolled but did not complete a school year.

TABLE 2

Number of Years of School Completed by Children in Study Sample

\begin{tabular}{|c|c|c|c|c|c|c|c|c|}
\hline & \multicolumn{7}{|c|}{ Years of School Completed } & \multirow[b]{2}{*}{ Total } \\
\hline & 0 & 1 & 2 & 3 & 4 & 5 & 6 & \\
\hline $\begin{array}{l}\text { Boys........... } \\
\text { Girls....... }\end{array}$ & $\begin{array}{l}67 \\
70\end{array}$ & $\begin{array}{l}49 \\
34\end{array}$ & $\begin{array}{l}31 \\
32\end{array}$ & $\begin{array}{l}21 \\
21\end{array}$ & $\begin{array}{l}21 \\
26\end{array}$ & $\begin{array}{l}7 \\
5\end{array}$ & $\begin{array}{l}1 \\
2\end{array}$ & $\begin{array}{l}197 \\
190\end{array}$ \\
\hline
\end{tabular}

1 The fourth village participating in the INCAP study was excluded from analyses because of noncomparability of its educational situation. The school in this community has until recently had only first through third grades, and some children who attend school have been sent to a school in a larger town nearby. 
The 22-test INCAP Preschool Battery was adapted to the research setting by a team consisting of American and Guatemalan psychologists, a Guatemalan cultural anthropologist, and Guatemalan testers and cultural informants (Klein, Gilbert, Canosa, \& de León, Note 3 ). A series of validity studies (Irwin, Klein, Engle, Yarbrough, \& Nerlove 1977) has established that in general the battery is both meaningful in terms of the conceptual universe of the study communities and possesses construct validity in the context of Western social science. Acceptable test-retest and intertester reliability has also been demonstrated (Note 4).
In the present paper, scores received at age 7 for each of the 18 tests in the battery which are designed to measure cognitive skills (as opposed to motoric or affective traits) are employed. These tests are listed in table 3. Also employed is a composite score constructed by summing standardized (for 7-year-olds, within sex) scores for each of these tests.

Family variables.-In addition to cognitive measurements, INCAP has also collected information relating to the social environment and economic status of the family of each child participating in the study. Family income data have been collected but found to fluctuate greatly from year to year and are difficult to

TABLE 3

Means and $t$ Values of Preschool Tests, for Children Schooled versus Unschooled

\begin{tabular}{|c|c|c|c|c|c|c|}
\hline & \multicolumn{3}{|c|}{ Boys } & \multicolumn{3}{|c|}{ GIRLS } \\
\hline & Schooled & Unschooled & $t$ & Schooled & Unschooled & $t$ \\
\hline Composite score....... & $\begin{array}{l}1.21 \\
(130)\end{array}$ & $\begin{array}{r}-1.19 \\
(67)\end{array}$ & $1.93^{*}$ & $\begin{array}{l}1.41 \\
(120)\end{array}$ & $\begin{array}{r}-3.55 \\
(70)\end{array}$ & $4.28^{* *}$ \\
\hline Picture vocabulary recognition...... & $\begin{array}{r}35.91 \\
(128)\end{array}$ & $\begin{array}{r}35.15 \\
(67)\end{array}$ & $1.77^{*}$ & $\begin{array}{c}35.81 \\
(118)\end{array}$ & 33.75 & $4.16^{* *}$ \\
\hline Verbal analogies. . & $\begin{array}{l}7.48 \\
(128)\end{array}$ & $\begin{array}{r}7.13 \\
(66)\end{array}$ & 1.26 & $\begin{array}{l}6.90 \\
(118)\end{array}$ & $\begin{array}{r}6.12 \\
(67)\end{array}$ & $2.54^{* *}$ \\
\hline Digit span.. & $\begin{aligned} 47.83 \\
(127)\end{aligned}$ & $\begin{array}{r}43.89 \\
(66)\end{array}$ & $1.74^{*}$ & $\begin{array}{c}49.21 \\
(117)\end{array}$ & $\begin{array}{r}44.39 \\
(69)\end{array}$ & $2.02^{*}$ \\
\hline Word span..$\ldots \ldots \ldots$ & $\begin{aligned} 84.24 \\
(128)\end{aligned}$ & $\begin{array}{r}77.73 \\
(66)\end{array}$ & $1.86^{*}$ & $\begin{array}{l}79.30 \\
(119)\end{array}$ & $\begin{array}{r}72.71 \\
(69)\end{array}$ & $1.80^{*}$ \\
\hline Discrimination learning. . & $\begin{aligned} 37.98 \\
(127)\end{aligned}$ & $\begin{array}{r}35.43 \\
(67)\end{array}$ & .82 & $\begin{array}{r}36.57 \\
(119)\end{array}$ & $\begin{array}{l}32.24 \\
(70)\end{array}$ & 1.41 \\
\hline Memory for objects. . & $\begin{array}{l}8.41 \\
(56)\end{array}$ & $\begin{array}{r}7.74 \\
(38)\end{array}$ & .91 & $\begin{array}{r}8.44 \\
(41)\end{array}$ & $\begin{array}{c}8.36 \\
(44)\end{array}$ & .25 \\
\hline Memory for pictures. . & $\begin{array}{l}3.80 \\
(128)\end{array}$ & $\begin{array}{l}3.64 \\
(67)\end{array}$ & .71 & $\begin{array}{l}3.77 \\
(119)\end{array}$ & $\begin{array}{r}3.64 \\
(70)\end{array}$ & .63 \\
\hline Memory for designs... & $\begin{array}{l}41.22 \\
(122)\end{array}$ & $\begin{array}{r}33.95 \\
(66)\end{array}$ & $2.47^{* *}$ & $\begin{aligned} 37.47 \\
(118)\end{aligned}$ & $\begin{array}{r}32.82 \\
(67)\end{array}$ & $1.84^{*}$ \\
\hline Block design copying... & $\begin{array}{r}85.00 \\
(54)\end{array}$ & $\begin{aligned} 76.24 \\
(38)\end{aligned}$ & 1.53 & $\begin{array}{c}80.71 \\
(42)\end{array}$ & $\begin{array}{r}71.16 \\
(45)\end{array}$ & 1.59 \\
\hline Embedded figures. & $\begin{array}{l}7.47 \\
(128)\end{array}$ & $\begin{array}{r}7.31 \\
(67)\end{array}$ & .50 & $\begin{array}{l}7.58 \\
(119)\end{array}$ & $\begin{array}{r}6.77 \\
(69)\end{array}$ & $2.34^{*}$ \\
\hline Incomplete figures . ...... & $\begin{array}{l}9.80 \\
(56)\end{array}$ & $\begin{array}{r}9.89 \\
(38)\end{array}$ & -.17 & $\begin{array}{c}9.67 \\
(42)\end{array}$ & $\begin{array}{r}7.80 \\
(46)\end{array}$ & $2.85^{* *}$ \\
\hline Elimination of odd picture. & $\begin{array}{l}8.48 \\
(54)\end{array}$ & $\begin{array}{l}8.34 \\
(38)\end{array}$ & .22 & $\begin{array}{r}9.02 \\
(42)\end{array}$ & $\begin{array}{r}7.30 \\
(44)\end{array}$ & $2.87^{* *}$ \\
\hline Matching familiar figures... & $\begin{array}{l}4.06 \\
(127)\end{array}$ & $\begin{array}{r}3.87 \\
(67)\end{array}$ & .73 & $\begin{array}{l}4.08 \\
(118)\end{array}$ & $\begin{array}{r}3.59 \\
(70)\end{array}$ & $2.19^{*}$ \\
\hline Knox cubes. . & $\begin{array}{r}10.19 \\
(57)\end{array}$ & $\begin{array}{r}9.90 \\
(39)\end{array}$ & .20 & $\begin{array}{c}8.28 \\
(43)\end{array}$ & $\begin{array}{c}7.11 \\
(44)\end{array}$ & 1.11 \\
\hline Animal house.... & $\begin{array}{r}226.95 \\
(56)\end{array}$ & $\begin{array}{r}219.74 \\
(38)\end{array}$ & .26 & $\begin{array}{r}273.85 \\
(41)\end{array}$ & $\begin{aligned} 212.84 \\
(44)\end{aligned}$ & $2.98^{* *}$ \\
\hline Conservation of material. & $\begin{array}{l}.96 \\
(53)\end{array}$ & $\begin{array}{l}.76 \\
(38)\end{array}$ & 1.08 & $\begin{array}{l}.68 \\
(41)\end{array}$ & .66 & .14 \\
\hline Conservation of liquid. . & .84 & .53 & $1.86^{*}$ & $\begin{array}{l}.68 \\
(41)\end{array}$ & $\begin{array}{l}.40 \\
(45)\end{array}$ & $1.91^{*}$ \\
\hline Conservation of area. & $\begin{array}{r}1.23 \\
(56)\end{array}$ & $\begin{array}{r}1.16 \\
(38)\end{array}$ & .40 & $\begin{array}{r}1.32 \\
(41)\end{array}$ & $\begin{array}{l}.81 \\
(43)\end{array}$ & $2.71^{* *}$ \\
\hline
\end{tabular}

NoTE.-Figures in parentheses represent number of cases; tests with smaller numbers were added to the battery in 1971.

$* p<.05$, one-tailed.

$* * p<.01$, one-tailed. 
interpret. To characterize family economic status, a stable index of wealth (test-retest $r$ 's over 2-year intervals $>.9$ ) based on the size and construction of the family's house has been obtained four times since 1967, as has an index of parents' clothing (simply the use of sweater and shoes by mother and father) which appears to reflect both family means and social status in these communities. Collected at the same time were data for one measure of intellectual stimulation: mothers' reports of attempts to teach preschoolers in the home.

In 1975, mothers' and fathers' education (years of school attended), mothers' modernity (using an adapted version of the Overall Modernity scale [Inkeles \& Smith 1974]), mothers' vocabulary (using an adapted version of the WISC vocabulary subtest), and amount of toys, books, and other potentially stimulating material objects in each family's home were also measured.

Children in the sample were of different ages when these family variables were measured, raising the possibility that children were differentially affected by these variables as a function of their age-cohort membership. The parental education measures have not changed during the time period of the study, however, and it is our general impression that the other family variables probably also have maintained a high level of stability.

Schooling history.-Schooling data have been taken from two sources: village teacher roll books (for years of enrollment), and the records of the central office of the Guatemalan Ministry of Education in the capital. The latter is the only accurate source of information on actual presence in school and performance. Because ministry records are kept only for children who complete the school year, whole years are employed as our unit of measurement for attendance.

\section{Results}

Attendance versus nonattendance.-The first question addressed in data analyses was whether sample children who attended school for a year or more up to the time of data compilation differed previous to schooling opportunities from children who never attended. For these analyses the six age cohorts have been aggregated to increase power and economy of presentation, since previous analyses have established that the relationship of early intellectual ability and of family characteristics with subsequent school attendance is consistent across cohorts. This consistency across cohorts is not surprising since little evidence of significant change in the study communities, including secular change in children's mental test performances, has been observed in the 8 years that INCAP's longitudinal study has been in existence.

Univariate comparisons of schooled and nonschooled sample children for each of the 18 Preschool Battery cognitive tests, as well as for the composite score, are presented in table 3 . We have also performed multivariate analyses of variances incorporating the 18 test variables since these test scores are not mutually independent. These analyses indicate significant multivariate $F$ 's for both boys $(F=5.02$, $p<.05)$ and girls $(F=8.83, p<.01)$. However, since some tests were added to the Preschool Battery later than others, and a number of children missed one or more tests, data for relatively few children ( 85 boys and 76 girls) were complete for all 18 tests and thus considered in these analyses. The univariate comparisons are thus of greater interest.

As table 3 indicates, there is ample evidence that children who were tested previous to schooling opportunities and who subsequently attended school were intellectually more able than peers who did not attend. Not only are significant differences seen for the composite score as well as for many individual tests, but among sample boys 17 of 18 test score differences favor those children who subsequently attended school. Among sample girls all 18 score differences favor those who subsequently attended school.

We have also compared children who attended or did not attend school up to the time of data compilation on several family variables. These data are described in table 4 . Here again, the various individual comparisons are not independent, but individual variables are of descriptive interest, and the overall picture is one of consistent and visible differences in the characteristics of families of school attending versus nonattending children.

Length of school attendance.-A second set of analyses examines the relationship among length (in years) of school attendance, intellectual ability previous to schooling opportunities, and family characteristics. All children in 
TABLE 4

Means and $t$ Values of Family Variables, for Children Schooled versus Unschooled

\begin{tabular}{|c|c|c|c|c|c|c|}
\hline & \multicolumn{3}{|c|}{ Boys } & \multicolumn{3}{|c|}{ GIRLS } \\
\hline & $\underset{\text { Schooled }}{M}$ & $\begin{array}{c}M \\
\text { Unschooled }\end{array}$ & $t$ & $\begin{array}{c}M \\
\text { Schooled }\end{array}$ & $\begin{array}{c}M \\
\text { Unschooled }\end{array}$ & $t$ \\
\hline House... & . 23 & -.20 & $3.57^{* *}$ & (121) & -.35 & $3.60^{* *}$ \\
\hline Parents' clothing. & (128) & -.21 & $2.76^{* *}$ & (121) & $\begin{array}{r}-.20 \\
(85)\end{array}$ & $2.30^{*}$ \\
\hline Material stimulation. . & $\begin{array}{l}.90 \\
(90)\end{array}$ & $\begin{array}{l}.32 \\
(50)\end{array}$ & 1.17 & $\begin{array}{l}.10 \\
(85)\end{array}$ & $\begin{array}{r}-.13 \\
(57)\end{array}$ & $2.51^{* *}$ \\
\hline Teaching.......... & $\begin{array}{l}.34 \\
(128)\end{array}$ & $\begin{array}{r}-.01 \\
(75)\end{array}$ & $3.34^{* *}$ & (121) & $\begin{array}{l}.03 \\
(85)\end{array}$ & $1.69^{*}$ \\
\hline Mother's vocabulary & $\begin{array}{r}6.98 \\
(91)\end{array}$ & $\begin{array}{r}4.86 \\
(52)\end{array}$ & $3.58^{* *}$ & $\begin{array}{c}6.01 \\
(86)\end{array}$ & $\begin{array}{r}5.07 \\
(57)\end{array}$ & 1.60 \\
\hline Mother's schooling. & $\begin{array}{r}2.00 \\
(89)\end{array}$ & $\begin{array}{r}1.82 \\
(47)\end{array}$ & .62 & $\begin{array}{r}2.09 \\
(82)\end{array}$ & 1.62 & $1.73^{*}$ \\
\hline Father's schooling. . . & $\begin{array}{r}1.55 \\
(84)\end{array}$ & $\begin{array}{l}.88 \\
(43)\end{array}$ & $2.03 *$ & $\begin{array}{l}.92 \\
(76)\end{array}$ & $\begin{array}{r}1.53 \\
(51)\end{array}$ & $-2.13^{*}$ \\
\hline Mother's modernity............ & $\begin{array}{l}.47 \\
(91)\end{array}$ & $\begin{array}{l}.38 \\
(50)\end{array}$ & $3.42^{* *}$ & $\begin{array}{l}.43 \\
(83)\end{array}$ & $\begin{array}{l}.42 \\
(57)\end{array}$ & .33 \\
\hline
\end{tabular}

Note.-Figures in parentheses represent number of cases.

$* p<.05$, one-tailed.

$* * p<.01$, one-tailed.

the sample are included in these analyses, with children who never attended a year of school to the time of data compilation being credited with zero years of attendance. Simple correlations between Preschool Battery scores and family variables and years of attendance are presented in tables 5 and 6 , respectively.

As table 5 indicates, a moderate association exists between preschool test performances and years of school subsequently attended, with somewhat higher correlations generally seen for girls than for boys. As table 6 indicates, a stronger association, particularly for boys, exists between several family variables and years of school attended.

In order to assess the unique contributions of intellectual ability previous to schooling opportunities and family characteristics to length of school attendance, a series of multiple regression analyses were performed. For these analyses the Preschool Battery composite score is used as our indicator of early intellectual ability, and family variables are divided into SES indicators (house and parents' clothing) and indicators of family values relating to schooling (father's schooling, mother's schooling, and mother's modernity score).

To determine the unique contribution of early intellectual ability to length of school attendance, the composite score was regressed on length of attendance after first forcing the

SES and values indicators into the regression equation. For boys, the resulting partial correlation of composite score with years of attendance is not significant $(r=.06)$. For girls, however, early intellectual ability does predict length of attendance, explaining a significant, though modest, portion of the variance in length of attendance even after controlling for family SES and values related to schooling (partial $r=.16, p<.05$, one-tailed).

The contribution of family SES to length of attendance was assessed by separately regressing house and parents' clothing on attendance, in each case after first forcing in the composite score and values indicators. For boys, family SES level does explain a significant portion of the variance in length of attendance after controlling for early intellectual ability and family values (partial $r$ for house $=.19, p<.05$; partial $r$ for parents' clothing $=.17, p<.05$, one-tailed). For girls, family SES does not continue to relate significantly to length of attendance (partial $r$ for house = .10 ; partial $r$ for parents clothing $=.10$ ).

The contribution of family values was assessed by separately regressing father's schooling, mother's schooling, and mother's modernity on length of attendance, in each case after first forcing in the composite score and SES indicators. Only mother's modernity continues to explain a significant portion of the variance in length of attendance, and only for boys 
(partial $r=.17, p<.05$, one-tailed), with all other partial correlations of family values related to schooling and length of attendance being near zero for both sexes.

Multiple $r^{2}$ values for the composite score plus all family SES and values variables with length of attendance are relatively modest for both boys $\left(r^{2}=.16\right)$ and girls $\left(r^{2}=.08\right)$, indicating that most of the variance in length of attendance is not explained by variables employed in our regression analyses.

Age at first enrollment.-Also examined are the relationships of early intellectual ability and family characteristics with the age at which a child was first enrolled in school. Included in these analyses are only those children who had enrolled in school to the time of data compilation. Sample sizes are larger than those

TABLE 5

Correlations between Preschool Battery Performances at 7 Years Old and Age at Which Child Was First Enrolled in School, Length of Attendance, and Average

School Grades in Mathematics and Language

\begin{tabular}{|c|c|c|c|c|c|c|c|c|}
\hline & \multirow{2}{*}{\multicolumn{2}{|c|}{$\begin{array}{l}\text { LENGTH OF } \\
\text { ATTENDANCE }\end{array}$}} & \multirow{2}{*}{\multicolumn{2}{|c|}{$\begin{array}{c}\text { AGE AT } \\
\text { ENROLLMENT }\end{array}$}} & \multicolumn{4}{|c|}{ SCHOOL ACHIEVEMENT } \\
\hline & & & & & \multicolumn{2}{|c|}{ Boys } & \multicolumn{2}{|c|}{ Girls } \\
\hline & Boys & Girls & Boys & Girls & Math. & Lang. & Math. & Lang. \\
\hline Compos & $\begin{array}{l}.14 \\
(197)^{\mathrm{a}}\end{array}$ & $\begin{array}{l}.22 * * \\
(190)\end{array}$ & $\begin{array}{c}-.34^{* *} \\
(152)^{\mathrm{b}}\end{array}$ & $\begin{array}{c}-.28^{* *} \\
(142)\end{array}$ & $\begin{array}{l}.39^{* *} \\
(130)^{\circ}\end{array}$ & $\begin{array}{l}.45^{* *} \\
(130)\end{array}$ & $\begin{array}{l}.34 * * \\
(129)\end{array}$ & ${ }_{(120)}^{.34^{* *}}$ \\
\hline ogn & .08 & $.23 * *$ & $-.16^{*}$ & -.14 & $.37^{* *}$ & $.46^{* *}$ & $.25 * *$ & $.24^{* *}$ \\
\hline Verbal analogies.. & $\begin{array}{l}(195) \\
.13 \\
(104)\end{array}$ & $\begin{array}{l}(188) \\
.22^{* * *}\end{array}$ & $\begin{array}{l}(150) \\
-.24^{* *}\end{array}$ & & $\begin{array}{l}(128) \\
.24^{* *}\end{array}$ & $\begin{array}{l}(128) \\
.27 * *\end{array}$ & & $\begin{array}{l}(118) \\
.40^{* *}\end{array}$ \\
\hline Digit span & (194) & $\begin{array}{l}(185) \\
.22^{* *}\end{array}$ & $\begin{array}{l}(150) \\
-.24^{* *}\end{array}$ & $\begin{array}{r}(140) \\
-.13\end{array}$ & $\begin{array}{l}(128) \\
.22^{*}\end{array}$ & $\begin{array}{l}(128) \\
.15\end{array}$ & $\begin{array}{l}(118) \\
.22^{*}\end{array}$ & $\begin{array}{l}(118) \\
.19^{*}\end{array}$ \\
\hline Word span & $\begin{array}{l}\text { (193) } \\
.155^{*}\end{array}$ & $\begin{array}{l}(186) \\
.09 \\
(110)\end{array}$ & $\begin{array}{c}(149) \\
-.22 * * \\
\end{array}$ & $\begin{array}{r}(139) \\
-.14\end{array}$ & $\begin{array}{l}(127) \\
.28 * *\end{array}$ & $\begin{array}{l}(127) \\
.31^{* *}\end{array}$ & (117) & (117) \\
\hline Discrimination learning. & $\begin{array}{l}.08 \\
(194)\end{array}$ & $\begin{array}{l}.14^{*} \\
(189)\end{array}$ & $\begin{array}{c}(150) \\
-.05 \\
(149)\end{array}$ & $\begin{array}{r}(141) \\
-.15 \\
(141)\end{array}$ & $\begin{array}{l}(128) \\
.15 \\
(127)\end{array}$ & $\begin{array}{l}(128) \\
.09 \\
(127)\end{array}$ & $\begin{array}{l}(119) \\
.16 \\
(119)\end{array}$ & $\begin{array}{l}(119) \\
.13 \\
(119)\end{array}$ \\
\hline Memory for objects. . & $\begin{array}{l}.15 \\
(94)\end{array}$ & $\begin{array}{r}-.01 \\
(85)\end{array}$ & $\begin{array}{c}-.30^{*} \\
(67)\end{array}$ & $\begin{array}{r}-.27^{*} \\
(54)\end{array}$ & $\begin{array}{l}.29^{*} \\
(56)\end{array}$ & $\begin{array}{r}-.16 \\
(41)\end{array}$ & $\begin{array}{l}.25 \\
(56)\end{array}$ & $\begin{array}{r}-.11 \\
(41)\end{array}$ \\
\hline Memory for $\mathrm{p}$ & $\begin{array}{l}.05 \\
(195)\end{array}$ & $\begin{array}{r}-.01 \\
(189)\end{array}$ & $\begin{array}{c}-.28^{* *} \\
(150)\end{array}$ & $\begin{array}{c}-.28^{* *} \\
(141)\end{array}$ & $\begin{array}{l}.30^{* *} \\
(128)\end{array}$ & $\begin{array}{l}.33^{* *} \\
(128)\end{array}$ & (119) & (119) \\
\hline Memory for designs & $\begin{array}{l}.06 \\
(188)\end{array}$ & $\begin{array}{l}.09 \\
(185)\end{array}$ & $\begin{array}{c}-.22 * * \\
(144)\end{array}$ & $\begin{array}{c}-.22^{* *} \\
(140)\end{array}$ & $\left(28^{* *}\right.$ & $\begin{array}{l}\left(37^{* *}\right. \\
(122)\end{array}$ & $\begin{array}{l}.10 \\
\text { (118) }\end{array}$ & $\begin{array}{l}.05 \\
\text { (118) }\end{array}$ \\
\hline Block design copying. ... & $\begin{array}{l}.23^{*} \\
(92)\end{array}$ & $\begin{array}{l}.11 \\
(87)\end{array}$ & $\begin{array}{c}-40^{* *} \\
(65)\end{array}$ & $\begin{array}{c}-.36^{* *} \\
(55)\end{array}$ & $\begin{array}{l}.20 \\
(54)\end{array}$ & $\begin{array}{l}.26 \\
(56)\end{array}$ & $\begin{array}{l}.09 \\
(42)\end{array}$ & $\begin{array}{l}.07 \\
(42)\end{array}$ \\
\hline Embedded figur & $\begin{array}{l}.01 \\
(195)\end{array}$ & $\begin{array}{l}.21^{* *} \\
(188)\end{array}$ & $\begin{array}{c}-.21^{*} \\
(150)\end{array}$ & $\begin{array}{r}-.12 \\
(141)\end{array}$ & (128) & $\begin{array}{l}.25^{* *} \\
(128)\end{array}$ & $\begin{array}{l}.15 \\
\text { (119) }\end{array}$ & $\begin{array}{c}.07 \\
(119)\end{array}$ \\
\hline Incomplete figures. & $\begin{array}{l}.08 \\
(94)\end{array}$ & $\begin{array}{l}.30^{* *} \\
(88)\end{array}$ & $\begin{array}{c}-.28^{*} \\
(67)\end{array}$ & -.21 & $\begin{array}{l}.29^{*} \\
(56)\end{array}$ & $\begin{array}{l}.28^{*} \\
(56)\end{array}$ & $\begin{array}{l}.16 \\
(42)\end{array}$ & $\begin{array}{l}.32^{*} \\
(42)\end{array}$ \\
\hline $\begin{array}{r}\text { Elimi } \\
\text { tur }\end{array}$ & $\begin{array}{l}.13 \\
(92)\end{array}$ & $\begin{array}{l}.30^{* *} \\
(86)\end{array}$ & $-\frac{.36^{* *}}{(65)}$ & $-.37^{* *}$ & $\begin{array}{l}.20 \\
(54)\end{array}$ & $\begin{array}{l}.24 \\
(54)\end{array}$ & $\begin{array}{l}.18 \\
(42)\end{array}$ & $.31^{*}$ \\
\hline Matching familiar figures & (194) & $\begin{array}{c}.05 \\
\text { (i88) }\end{array}$ & $\begin{array}{r}-.15 \\
(149)\end{array}$ & $\begin{array}{r}-.08 \\
(140)\end{array}$ & $\begin{array}{l}.14 \\
\text { (127) }\end{array}$ & $\begin{array}{l}.22^{*} \\
(127)\end{array}$ & $\begin{array}{l}.18^{*} \\
(118)\end{array}$ & $\begin{array}{c}.16 \\
(118)\end{array}$ \\
\hline Knox cubes. & $\begin{array}{l}.11 \\
(96)\end{array}$ & $\begin{array}{l}.14 \\
(87)\end{array}$ & $\begin{array}{c}-.42^{* *} \\
(69)\end{array}$ & $\begin{array}{r}-.25 \\
(56)\end{array}$ & $\begin{array}{l}.02 \\
(57)\end{array}$ & $\begin{array}{l}.04 \\
(57)\end{array}$ & $\begin{array}{l}.15 \\
(43)\end{array}$ & .22 \\
\hline Animal house & $\begin{array}{l}.14 \\
(94)\end{array}$ & $\begin{array}{l}.29^{*} \\
(85)\end{array}$ & $\begin{array}{r}-.28^{*} \\
(67)\end{array}$ & $\begin{array}{r}-.33^{*} \\
(54)\end{array}$ & .23 & $\begin{array}{l}.30^{*} \\
(56)\end{array}$ & $\begin{array}{l}.35^{*} \\
(41)\end{array}$ & $\begin{array}{l}.30 \\
(41)\end{array}$ \\
\hline Conservation of material & $\begin{array}{l}.24^{*} \\
(91)\end{array}$ & $\begin{array}{r}-.09 \\
(85)\end{array}$ & $\begin{array}{r}-.17 \\
(64)\end{array}$ & -.06 & $\begin{array}{l}.30^{*} \\
(53)\end{array}$ & $\begin{array}{l}.37^{* *} \\
(53)\end{array}$ & -.04 & $\begin{array}{r}-.12 \\
(41)\end{array}$ \\
\hline Conservation of liquid... & $\begin{array}{l}.24 * \\
(93)\end{array}$ & $\begin{array}{l}.02 \\
(86)\end{array}$ & -.13 & -.06 & .24 & $\begin{array}{l}.30^{*} \\
(55)\end{array}$ & -.22 & -.29 \\
\hline Conservation of area. & $\begin{array}{l}.17 \\
(94)\end{array}$ & $\begin{array}{l}.25^{*} \\
(84)\end{array}$ & $\begin{array}{c}-.43^{* *} \\
(67)\end{array}$ & $\begin{array}{r}-.10 \\
(54)\end{array}$ & $\begin{array}{l}.26^{*} \\
(56)\end{array}$ & $\begin{array}{l}.39^{* *} \\
(56)\end{array}$ & -.01 & $\begin{array}{r}-.03 \\
(41)\end{array}$ \\
\hline
\end{tabular}

- Numbers for length of attendance analyses include all children, including those who did not attend school.

b Numbers for age of enrollment analyses include only those children who enrolled in school.

- Numbers for school achievement analyses include only those children who not only enrolled but also completed a year or more of school.

$* p<.05$, one-tailed.

$* * p<.01$, one-tailed. 
TABLE 6

Correlations between Various Family Indices and Number of Years of School Attended, Age at Which Child Was First Enrolled in School, and Average School

Grades in Mathematics and Language

\begin{tabular}{|c|c|c|c|c|c|c|c|c|}
\hline & \multirow{2}{*}{\multicolumn{2}{|c|}{$\begin{array}{l}\text { LENGTH OF } \\
\text { ATTENDANCE }\end{array}$}} & \multirow{2}{*}{\multicolumn{2}{|c|}{$\begin{array}{c}\text { AGE AT } \\
\text { ENROLLMENT }\end{array}$}} & \multicolumn{4}{|c|}{ School ACHIEVEMENT } \\
\hline & & & & & \multicolumn{2}{|c|}{ Boys } & \multicolumn{2}{|c|}{ Girls } \\
\hline & Boys & Girls & Boys & Girls & Math. & Lang. & Math. & Lang. \\
\hline House & $\stackrel{24^{* *}}{(203) \mathrm{a}}$ & .23** & -.12 & $-.26^{* *}$ & . $22^{*}$ & (198* & (i21) & .00 \\
\hline Parents' clothing. & (23)** & $\begin{array}{l}.18^{*} \\
(206)\end{array}$ & $\begin{array}{c}-.23^{* * *} \\
(150)\end{array}$ & $\begin{array}{c}-.24^{* *} \\
(145)\end{array}$ & . $20^{*}$ & (125** & .16 & (121) \\
\hline Material stimulation.... & (i40) & $\begin{array}{l}.24 * * \\
(142)\end{array}$ & $\begin{array}{l}-.18 \\
-(105)\end{array}$ & $\begin{array}{r}-.16 \\
-(103)\end{array}$ & $\begin{array}{l}.49 * * \\
(90)\end{array}$ & $\begin{array}{l}.44^{* *} \\
(90)\end{array}$ & $\begin{array}{l}.25^{*} \\
(85)\end{array}$ & $\begin{array}{l}.18 \\
(85)\end{array}$ \\
\hline Teaching. . & $\begin{array}{l}.22 * * \\
(203)\end{array}$ & $\begin{array}{l}.14^{*} \\
(206)\end{array}$ & $\begin{array}{r}-.10 \\
(150)\end{array}$ & -.12 & $\begin{array}{l}.01 \\
(128)\end{array}$ & $\begin{array}{c}.08 \\
(128)\end{array}$ & $.21 *$ & $\begin{array}{r}18 \\
.181)\end{array}$ \\
\hline Mother's vocabulary.... & $\begin{array}{l}.28^{* *} \\
(143)\end{array}$ & $\begin{array}{l}.21^{*} \\
(143)\end{array}$ & $\begin{array}{c}-.24^{*} \\
(107)\end{array}$ & $\begin{array}{r}-.07 \\
(104)\end{array}$ & $\begin{array}{l}.11 \\
(91)\end{array}$ & $\begin{array}{l}.01 \\
(91)\end{array}$ & $\begin{array}{l}.16 \\
(86)\end{array}$ & $\begin{array}{l}.12 \\
(86)\end{array}$ \\
\hline Mother's schooling. & .04 & $\begin{array}{l}.09 \\
(137)\end{array}$ & (106) & $\begin{aligned}-.10 \\
(100)\end{aligned}$ & $\begin{array}{l}.16 \\
(89)\end{array}$ & .08 & $\begin{array}{l}-.19 \\
-(82)\end{array}$ & $-.22^{*}$ \\
\hline Father's schooling. . & (127) & $\begin{array}{r}-.09 \\
-(127)\end{array}$ & $\begin{array}{l}.01 \\
(98)\end{array}$ & $\begin{array}{l}.04 \\
(92)\end{array}$ & . $87^{*}$ & $\begin{array}{l}.24^{*} \\
(84)\end{array}$ & $\begin{array}{l}.06 \\
(76)\end{array}$ & $\begin{array}{l}.03 \\
(76)\end{array}$ \\
\hline Mother's modernity. & $\begin{array}{l}\text { (141) } \\
\text { (141** }\end{array}$ & $\begin{array}{l}.15 \\
(140)\end{array}$ & $\begin{array}{r}-.15 \\
-(106)\end{array}$ & $\begin{array}{r}-.15 \\
(101)\end{array}$ & $\begin{array}{l}.18 \\
(91)\end{array}$ & $\begin{array}{l}.12 \\
(91)\end{array}$ & $\begin{array}{l}.06 \\
(83)\end{array}$ & $\begin{array}{l}.07 \\
(83)\end{array}$ \\
\hline
\end{tabular}

- Numbers for length of attendance analyses include all children, including those who did not attend school.

b Numbers for age of enrollment analyses include only those children who enrolled in school.

- Numbers for school achievement analyses include only those children who not only enrolled but also finished a year or more of school.

$* p<.05$, one-tailed.

$* * p<.01$, one-tailed.

for the schooled group in the previous analyses, however, since children who enrolled but subsequently dropped out during their first year and never returned to school ( 26 boys and 32 girls) are included here. These children were identified by reviewing teachers' roll books, since the names of children who drop out of school generally are not recorded in the Ministry of Education records.

Simple correlations between Preschool Battery scores and family variables and age at first enrollment are presented in tables 5 and 6. As table 5 indicates, correlation coefficients for the composite score and for individual test scores and age at enrollment are consistently negative in direction, with the correlation being significant for the composite score and many individual tests. Thus children who performed well on mental tests at age 7 were more likely to enroll in school at younger ages than children who performed poorly. As table 6 indicates, family variables are less strongly related to age at first school enrollment. However, most of the family variable $\times$ age at enrollment correlations are also negative in direction, and a few (mother's vocabulary, and the SES indicators of house and parents' clothing) are significant for one or both sexes.
To assess the unique contribution of early intellectual ability and family characteristics to age at first enrollment, a series of multiple regression analyses parallel to those performed for length of attendance were run.

Regressing the composite score on length of attendance, after first forcing in family SES and family values indices, reveals that early intellectual ability does predict when a child first enrolls in school and explains a significant portion of the variance in the age at which a child was first enrolled in school even after controlling for family SES and values relating to schooling, particularly for boys. The partial correlation of the composite score and age at enrollment is $-.40 \quad(p<.01)$ for boys and -.20 ( $p<.05$, one-tailed) for girls.

Regressing separately house and parents' clothing on age at enrollment, in each case after forcing in the composite score and family values indices, indicates that family SES does explain a significant though modest portion of the variance in age at which children first enroll in school. The partial correlations of house with age at enrollment are - .06 (N.S.) for boys, and $-.18(p<.05$, one-tailed $)$ for girls. The partial correlations for parents' cloth- 
ing are $-.21(p<.05)$ for boys and -.06 (N.S.) for girls.

The indices of family values related to schooling (father's schooling, mother's schooling, mother's modernity) do not contribute significantly to the variance in age at first enrollment. Partial correlations for these variables are near zero or opposite to the direction predicted.

Multiple $r^{2}$ values for the composite score plus all family SES and values variables with age at first school enrollment are .21 for boys and .11 for girls, indicating that most of the variance in age at enrollment of sample children is not explained by variables employed in these regressions.

Causes of differential attendance patterns. -The significant associations seen among preschool mental test performances, attendance or nonattendance, length of attendance, and age at school entry suggest that parents are making schooling decisions on the basis of accurate perceptions of their children's intellectual development. To investigate this possibility, we examined the relationship of village adults' perceptions of children's intelligence to school attendance variables.

Data relating to such perceptions are available from a study performed on a small subsample of longitudinal study children in 1973, when these children were between 7 - and 9 -years-old. Village adults other than their parents ranked the children on listura (which is most often backtranslated to English as "smartness"), which is associated with the characteristics of alertness, verbal facility, good memory, independence, and a high level of physical activity. Listura scores in that study were found to correlate strongly with INCAP Preschool Battery scores (Klein, Freeman, Spring, Nerlove, \& Yarbrough 1976; Nerlove, Roberts, \& Klein, Note 5).

Boys who had attended school by the time data were compiled have mean listura scores significantly higher than boys who had not attended, $t(29)=2.37, p<.05$. Schooled girls also have higher listura scores than unschooled girls, $t(30)=3.68, p<.01$. Age at school entry does not correlate significantly with listura scores ( $r$ boys $=.10 ; r$ girls $=$ $.01)$. Length of attendance does correlate significantly with listura scores for both sexes ( $r$ boys $=.38, p<.05 ; r$ girls $=.52, p<.05)$. Though these data represent the perceptions not of parents but of other village adults, they suggest that parental perceptions of their children's intellectual ability may indeed influence whether or not they are enrolled in school and how long they are allowed to attend.

In trying to understand the poorer mental test scores of unschooled children we have also attempted to examine the role played by children who attempt school, find it too difficult, and drop out in their first year. Our analyses indicate that children who dropped out in their first year and never returned scored lower on pre-schooling mental tests than children who completed their first year of school ( $t$ composite score $=2.06, p<.05$, for boys; and 2.33, $p<.05$ for girls). Thus selfselection for schooling as well as parental selection may influence the relative abilities of school-attending and nonattending children.

School achievement.-We have also examined the relationship of mental test performances at 7 years of age and of family characteristics with school achievement. The sample for these analyses consists of the "schooled" children, who up to the time of data compilation had completed a year or more of school. The school achievement measures employed are average final grades in mathematics and language (the only grades given in first grade and the major ones in subsequent grades) for all years of school attended by each child. A grade of 60 in each subject is required for passing, and the average final grades received by boys in the sample were 66.96 (SD $=$ $15.04)$ in mathematics and $68.16(\mathrm{SD}=15.32)$ in language. The average final grades received by girls in the sample were $66.24(\mathrm{SD}=15.66$ ) in mathematics and 66.20 $(\mathrm{SD}=15.92)$ in language. These final grades represent the subjective judgment of the child's teacher. Beyond second grade an objective examination should constitute 50\% of the final grade assigned. However, here as well, the final grade reflects primarily the teacher's judgment, since there is considerable evidence in our schooling data of teachers adjusting their own component to compensate for national exam scores. Because of the number of teachers involved and the small size of classes in upper primary grades, we have not attempted to standardize these school achievement scores. Given the high probability of interteacher differences in grading practices, our estimates of the relationship of early intellectual ability and family characteristics with how much children learned in school may underestimate this relationship. 
Simple correlations between Preschool Battery performances at age 7 and mean grades received in mathematics and language are presented in table 5 . Before describing these relationships, we wish to emphasize once again that mental testing was always done prior to school entrance. Thus, these data address the question of whether, given that a child attended school, pre-schooling intellectual ability predicts school performance.

As table 5 indicates, 7 -year mental test scores do predict school grades, with the relationship being somewhat stronger for boys than for girls and for language grades than for mathematics grades. The most dramatic sex differences are seen for the conservation tasks, which are among the best predictors of school success for boys, yet show consistently negative (though nonsignificant) correlations for girls.

Simple correlations between family variables and school grades are presented in table 6 . These correlations are generally larger for boys than for girls, particularly for the family SES indicators of house and parents' clothing and the father's schooling variable, which are significantly related to school grades for boys but not for girls. The strongest association seen is between material stimulation in the home and school grades, particularly for boys.

As was done for length of attendance and age at enrollment, we have performed multiple regression analyses to investigate the unique contributions of early intellectual ability and family characteristics to school performance. For these analyses we again use the composite score as our index of intellectual ability previous to schooling opportunities and house and parents' clothing as indices of family SES level. A third group of variables employed in these regressions are several indices of intellectual stimulation available in the home. These are the material stimulation measure, mother's vocabulary score, teaching in the home, and the mother and father schooling variables. The latter two variables are included on the assumption that they reflect not only probable parental values concerning schooling but also the extent to which parents are able to stimulate their children's mental development (though parental education is extremely limited, with very few parents having gone beyond sixth grade, and mean amount of edu- cation being 1.30 years [SD $=1.69$ ] for fathers and 1.92 years [SD $=1.59$ ] for mothers).

Regressing the composite score on mean school mathematics and language scores, after first forcing in SES indicators and indicators of intellectual stimulation in the home, reveals that early intellectual ability predicts a significant portion of the variance in school grades, even after controlling for these other variables. The partial correlations of composite scores with mathematic grades are .09 (N.S.) for boys and $.44(p<.01)$ for girls. The partial correlations of composite scores with language grades are $.26(p<.05)$ for boys and .44 $(p<.01)$ for girls.

Family SES level explains relatively little variance in school grades after controlling for early intellectual ability and intellectual stimulation in the home. For girls, neither house nor parents' clothing shows a significant partial correlation with school grades. For boys, parents' clothing shows a marginally significant partial correlation with mean language score (partial $r=.19, p<.05$, one-tailed).

Regressing home stimulation measures separately on school grades, in each case after forcing in the composite score and SES indicators, reveals that some of these variables do explain significant portions of the variance in school grades, even after controlling for early intellectual ability and family SES level. For boys, material stimulation shows a partial correlation of $.38(p<.01)$ with mean mathematics grade and $.30(p<.01)$ with mean language grade. For girls, teaching shows a partial correlation of .30 ( $p<.01$, one-tailed) with both mean mathematics grade and mean language grade. Material stimulation shows a partial correlation of $.25(p<.05)$ with mean mathematics grade and .21 $(p<.05$, one-tailed) with mean language grade. In addition, mother's vocabulary shows a partial correlation of .19 (N.S.) with mean mathematics grade and a partial correlation of .22 $(p<.05$, onetailed) with mean language grade.

Multiple $r^{2}$ values for the composite score, SES indices, and measures of home stimulation with mean mathematics scores are .29 for boys and .31 for girls. Multiple $r^{2} s$ for these variables with mean language scores are .34 for boys and .31 for girls. Thus approximately a third of the variance in school grades is explained by our measurements of early intellectual ability and of family economic level and intellectual stimulation in the home. 


\section{Discussion}

Data presented in the present paper argue that in the rural Guatemalan setting of this study school attendance is dependent upon both a child's intellectual ability prior to schooling opportunities as well as characteristics of his or her family. Whether or not a child attended school during the 5-year period examined is related to mental test performances at age 7 , to family economic level, and to parental characteristics presumably indicative of values regarding the importance of education (i.e., parental education and modernity). The number of years of school a child attended during this period is predictable from 7-year mental test performances for girls but more related to family economic level and maternal modernity for boys. For those children of both sexes who enrolled in school during the time period examined, both 7-year test performances and family economic level, but not values relating to schooling, are predictive of the age at which a child first enrolled.

Within our Spanish-speaking study communities it is primarily the parents who make decisions concerning children's school enrollment. As we have noted, these parents appear to be making many of such decisions on the basis of accurate perceptions of their children's intellectual development. Data from a previous study (see Klein et al. 1976; Nerlove et al., Note 5) indicate that village adults' rankings of sample children's listura, or smartness, agree substantially with our own estimates based upon Preschool Battery performances.

Family economic level, parental education, and mother's modernity also appear to affect parents' schooling decisions. The value to these families of the labor of their schoolaged children is frequently considerable. Girls help their mothers with housework and both boys and girls care for younger siblings, thus freeing mothers for cash-generating activities, and boys help their fathers in the fields. Our data suggest that among these impoverished families, those of slightly higher socioeconomic status may be better able to cope with both the direct costs of educating their children, as well as with the loss of their schoolattending children's labor. Whether or not parents are inclined to make the sacrifices necessary to educate their children may depend upon parents' values concerning the impor- tance of schooling as reflected by their own educational levels and modernity.

The evidence we have presented that rural Guatemalan children who attend school, or begin school early, or remain in school a relatively long time are in some ways special has important implications for understanding the effects of formal education on intellectual development. The uniqueness of each cultural setting requires that generalizations to other settings be made cautiously. Nevertheless, important similarities exist between our study setting and others where schooling studies have been or are likely to be performed. Economic necessity is likely to dictate the need for selection of school attenders in many Third World communities, and those children sent to school or sent to school at young ages are likely to be brighter or more precocious than their peers. Even where economic necessity does not dictate the need for selection of students, parental values regarding the importance of schooling may affect which children attend.

Either selection of children for school on the basis of intellectual development or the covariance of relatively stimulating homes with the predisposition to send or keep children in school would make uninterpretable the kind of post hoc schooling effects study which has to date been undertaken. It is possible to study the effects of schooling in settings where some children receive formal instruction and others do not. What is required to do so, however, is a longitudinal design in which all children in a community (or a randomly selected subset) are tested before a portion of them enroll in school and then at one or more later points in time. Original differences between subsequently schooled and nonschooled children can thus be statistically controlled in assessing the effects of varying amounts of formal instruction. In addition, such a design permits assessment of the relationship between amount of schooling and intellectual development, because statistical control can be exerted over those factors associated with early school leaving. In assessing the effects of varying amounts of instruction, the ideal control is available for each child: the child itself. The present paper reports on the first phase of such a study which is presently in progress in the communities participating in INCAP's larger longitudinal study of the environmental bases of intellectual development. 
For those children who attended school between 1970 and 1975 in the study communities we have also investigated the correlates of good or poor school achievement. Both mental test performances prior to schooling opportunities and indices of intellectual stimulation provided in the home predict school grades, even after controlling for a variety of other factors. Family SES level, however, explains very little variance in school performance, after controlling for pre-schooling intellectual ability and home stimulation. We have seen that lower-SES children are less likely to be in school than peers from higherSES families. Poorer children in these communities are also likely to receive lower mental test scores than peers (Klein, Irwin, Engle, \& Yarbrough 1977). However, these data indicate that the bright child from a poorer family who does attend school, like the child from a poor but stimulating home, is likely to do well in school.

Our finding that mental test performances prior to schooling were associated with school performance contrasts with data for a much smaller sample $(N=33)$ reported earlier (Irwin et al. 1977). It suggests that in a rural Guatemalan Ladino setting, as in the industrialized West, success in school and success on mental test batteries require similar abilities.

\section{Reference Notes}

1. Sharp, D.; Cole, M.; \& Lave, C. Education and cognitive development: the evidence from experimental research. Unpublished manuscript, Rockefeller University, 1976.

2. Van Doorninck, W. J.; Caldwell, B. M.; Wright, C.; \& Frankenburg, W. K. The inventory of home stimulation as a predictor of school competence. Unpublished manuscript, 1976.

3. Klein, R. E.; Gilbert, O.; Canosa, C. A.; \& de León, R. Performance of malnourished in comparison with adequately nourished children on selected cognitive tasks (Guatemala). Paper presented at the annual meeting of the Association for the Advancement of Science, Boston, December 1969.

4. Division of Human Development, Institute of Nutrition of Central America and Panama. Progress report 1975 (for National Institute of Child Health and Human Development, Contract No. NO1-HD-5-0640). Guatemala: DDH, INCAP, 1975.
5. Nerlove, S. B.; Roberts, J. M.; \& Klein, R. E. Dimensions of "listura" (smartness): community judgments of rural Guatemalan children. Paper presented at the biennial meeting of the Society for Research in Child Development, Denver, April 1975.

\section{References}

Anastasi, A. Psychological testing (3d ed.). New York: Macmillan, 1968.

Bruner, J. S., \& Kenney, H. J. The development of the concepts of order and proportion in children. In J. S. Bruner, R. R. Olver, P. M. Greenfield, et al. (Eds.), Studies in cognitive growth. New York: Wiley, 1966.

Bruner, J. S.; Olver, R. R.; Greenfield, P. M.; et al. (Eds.), Studies in cognitive growth. New York: Wiley, 1966.

California School Administrators Association. The neighborhood and the school: a study of socioeconomic status and school achievement. Burlingame: California School Administrators Association, 1962.

Cole, M.; Gay, J.; Glick, J.; \& Sharp, D. The cultural context of learning and thinking. New York: Basic, 1971.

Cole, M., \& Scribner, S. Culture and thought: a psychological introduction. New York: Wiley, 1974.

Coleman, J. S. Equality of educational opportunity. Washington, D.C.: Government Printing Office, 1966.

Evans, J., \& Segall, M. Learning to classify by color and by function: a study of concept development by Ganda children. Journal of Social Psychology, 1969, 77, 35-53.

Fahrmeier, E. D. The effect of school attendance on intellectual development in northern $\mathrm{Ni}$ geria. Child Development, 1975, 46, 281-285.

Feldman, S., \& Weiner, M. The use of a standardized reading achievement test with two levels of socio-economic status pupils. Journal of Experimental Education, 1964, 32, 269-274.

Goodnow, J. J., \& Bethon, G. Piaget's tasks: the effects of schooling and intelligence. Child Development, 1966, 37, 573-582.

Greenfield, P. M., \& Bruner, J. S. Culture and cognitive growth. International Journal of Psychology, 1966, 1, 89.

Havighurst, R. J. The public schools of Chicago. Chicago: Board of Education of the City of Chicago, 1964.

Inkeles, A., \& Smith, D. H. Becoming modern: individual change in six developing countries. Cambridge, Mass.: Harvard University Press, 1974. 
Irvine, S. H. Towards a rationale for testing abilities and attainments in Africa. British Journal of Educational Psychology, 1966, 36, 24-32.

Irwin, M.; Klein, R. E.; Engle, P. L.; Yarbrough, C.; \& Nerlove, S. The problem of establishing validity in cross-cultural measurements. Annals of the New York Academy of Sciences, 1977, 285, 308-325.

Klein, R. E.; Freeman, H. E.; Spring, B.; Nerlove, S. B.; \& Yarbrough, C. Cognitive test performance and indigenous conceptions of intelligence. Journal of Psychology, 1976, 93, 273279.

Klein, R. E.; Irwin, M.; Engle, P. L.; \& Yarbrough, C. Malnutrition and mental development in rural Guatemala: an applied cross-cultural research study. In N. Warren (Ed.), Advances in cross-cultural psychology. New York: Academic Press, 1977.

Mejía-Pivaral, V. Características económicas y socioculturales de cuatro aldeas ladinas de Guatemala. Guatemala indígena, vol. 7, 1972.

Mermelstein, E., \& Shulman, L. Lack of formal schooling and the acquisition of conservation. Child Development, 1967, 33, 39-52.

Nerlove, S. B.; Roberts, J. M.; Klein, R. E.; Yarbrough, C.; \& Habicht, J. P. Natural indicators of cognitive development: an observational study of rural Guatemalan children. Ethos, 1974, 2, 265-295.

Okonji, M. A. Culture and children's understanding of geometry. International Journal of Psychology, 1971, 6, 121-128.

Owoc, P. J. On culture and conservation once again. International Journal of Psychology, 1973, 8, 249-254.

Page, H. W. Concepts of length and distance in a study of Zulu youths. Journal of Social Psychology, 1973, 90, 9-16.

$\rightarrow$ Price-Williams, D. R. A study concerning concepts of conservation of quantities among primitive children. Acta Psychologica, 1961, 18, 297305.

Price-Williams, D. R. Abstract and concrete modes of classification in a primitive society. British Journal of Educational Psychology, 1962, 32. $50-61$.

Scribner, S., \& Cole, M. Cognitive consequences of formal and informal education. Science, 1973, 182, 553-559.

Tuddenham, R. D. The nature and measurement of intelligence. In L. Postman (Ed.), Psychology in the making. New York: Knopf, 1963.

Tulkin, S. R. Race, class, family and social achievement. Journal of Personality and Social Psychology, 1968, 9, 31-37.

Vernon, P. E. Intelligence and cultural experience, London: Methuen, 1969.

Weiner, M., \& Feldman, S. Measurement of reading skills in lower socio-economic status children. New York: New York University School of Education, 1963. 